\title{
Formation age and tectonic environment of the Gantaohe Group, North China Craton: Geology, geochemistry, SHRIMP zircon geochronology and Hf-Nd isotopic systematics
}

\author{
XIE HangQiang ${ }^{1,2}$, LIU DunYi ${ }^{1,2}$, YIN XiaoYan ${ }^{3}$, ZHOU Hong Ying $^{4}$, YANG ChongHui ${ }^{1}$, \\ DU LiLin ${ }^{1} \&$ WAN YuSheng ${ }^{1,2 *}$ \\ ${ }^{1}$ Institute of Geology, Chinese Academy of Geological Sciences, Beijing 100037, China; \\ ${ }^{2}$ Beijing SHRIMP Center, Chinese Academy of Geological Sciences, Beijing 100037, China; \\ ${ }^{3}$ Chinese Academy of Geological Sciences, Beijing 100037, China; \\ ${ }^{4}$ Tianjin Institute of Geology and Mineral Resources, China Geological Survey, Tianjin 200170, China
}

Received April 28, 2012; accepted August 26, 2012

\begin{abstract}
The Gantaohe Group is an important early Precambrian unit in the Trans-North China Orogen, North China Craton, and is mainly composed of greenschist-facies metabasalt, meta-sandstone and dolomitic marble. We report whole-rock geochemical compositions and SHRIMP zircon ages as well as LA-ICP-MS Hf-in-zircon isotopeic analyses for metabasalts from the Gantaohe Group. SHRIMP dating yielded a weighted mean ${ }^{207} \mathrm{~Pb} /{ }^{206} \mathrm{~Pb}$ age of $2087 \pm 16 \mathrm{Ma}(\mathrm{MSWD}=1.3$ ) for magmatic zircons, but there are also abundant ca. $2.5 \mathrm{Ga}$ inherited zircon xenocrysts. The magmatic zircons shows a large $\varepsilon_{\mathrm{Hf}}(t)$ variation in $\varepsilon_{\mathrm{Hf}}(t)$ from -7.17 to +0.45 , suggesting an isotopically highly heterogeneous source for the metabasalt. Chemically all samples show no distinct $\mathrm{Zr}$ or $\mathrm{Hf}$ anomalies, and some samples show no $\mathrm{Nd}$ or Ta anomalies in a primitive mantle-normalized trace element variation diagram, and their whole-rock $\varepsilon_{\mathrm{Nd}}(t)$ values range from 4.0 to -0.8 . We suggest that the basalt is formed by partial melting of a depleted mantle source, followed by significant crustal contamination. Field observations, the presence of abundant inherited zircon, as well as isotope and trace elements geochemistry support formation of the Gantaohe Group on top of a continental basement. These data and the regional geology lead us to conclude that the Trans-North China Orogen constituted an intracontinental rift during the Paleoproterozoic that was connected to the Eastern Block since the end of the Archean.
\end{abstract}

Gantaohe Group, SHRIMP zircon dating, geochemistry, Paleoproterozoic, continental rift, North China Craton, Trans North China Orogen

Citation: Xie H Q, Liu D Y, Yin X Y, et al. Formation age and tectonic environment of the Gantaohe Group, North China Craton: Geology, geochemistry, SHRIMP zircon geochronology and Hf-Nd isotopic systematics. Chin Sci Bull, 2012, 57: 4735-4745, doi: 10.1007/s11434-012-5482-7

The North China Craton (NCC) experienced a long and complex evolution [1], and the strongest tectono-thermal event occurred at around $2.5 \mathrm{Ga}$, resulting in the formation of widespread supracrustal rocks and granitoids [2]. An important issue relating to the early Precambrian crustal evolution of the NCC is whether it became a large tectonic entity at the end of Neoarchean (ca. 2.5 Ga). Some models suggested that the NCC became a single crustal block at ca. $2.5 \mathrm{Ga}$, then experienced rifting during the middle Paleo-

*Corresponding author (email: wanyusheng@bjshrimp.cn) proterozoic, and was then consolidated, resulting in cratonization during late Paleoproterozoic [2-9]. Other models proposed that the NCC only became a single tectonic unit in the late Paleoproterozoic [10-20]. Zhao et al. [10] developed an important tectonic model, followed by many researchers [11-20], in which the Paleoproterozoic Trans-North China Orogen (TNCO) divides the NCC into two blocks, namely the Eastern and Western blocks. The origin and tectonic environment of Paleoproterozoic rock units in the TNCO are important to understand the orogenic evolution and to determine the time of NCC cratonization We report whole- 
rock geochemical data, SHRIMP zircon ages, and LA-ICPMS Hf-in-zircon isotopic analyses from metabasalt samples of the Gantaohe Group in the TNCO (Figure 1(a)), and discuss the formation environment of the Gantaohe Group and its tectonic significance.

\section{Geological background and sampling}

The main part of the Gantaohe Group rocks is exposed in Jingxing County, southwest of Shijiazhuang City, Hebei Province (Figure 1(b), (c)). The Zanhuang Complex constitutes the basement of the Gantaohe Group and is mainly composed of strongly deformed gneisses of the Archean tonalite-trondhjemite-granodiorite (TTG) suite, monzonitic granite plutons, and supracrustal rocks. The latter consist of amphibolite, marble, and biotite-plagioclase gneiss with amphibolite-to-granulite-facies metamorphism, locally reaching anatexis. The Gantaohe Group was interpreted to unconformably overlie the Zanhuang Complex [21], but it is difficult to find contacts between these units, and one wellpreserved exposure shows a tectonic contact. A $2.1 \mathrm{Ga}$ intrusive granitoid, named Xuting pluton, is located to the east of the Gantaohe Group and consists of dominating synogranite and minor monzogranite. The pluton generally shows a massive, unfoliated structure in most outcrops, but gneissic layering at the contact with the Gantaohe Group. All rocks mentioned above are covered unconformably by undeformed or weakly deformed conglomerate or sandstone of the Dongjiao Group or Changcheng Group (Figure 2(a)), both of which are coeval cover seqences of the stabilized NCC [22].

The Gantaohe Group is a thick lithostratigraphic sequence that experienced low greenschist-facies metamorphism. It is divided into four formations from the base upwards: (1) the Nansizhang Formation (472-2600 m): its lower part consists of conglomerate and feldspathic sandstone, whereas the upper part is dominated by basalt, volcanic breccia, chlorite schist and quartz-sericite schist; (2) the Nansi Formation (1000-4255 m): a succession of feldspathic sandstone, basalt, dolomite and shale; (3) the Haoting Formation (1700-2430 m): dolomite, sandstone and basalt; and (4) the Niushan Formation (>173 m): this unit consists of phyllite and shale but is not exposed in the research area [21]. Although folded, some primary structures and textures, such as basal conglomerate, graded-bedding and cross-bedding of

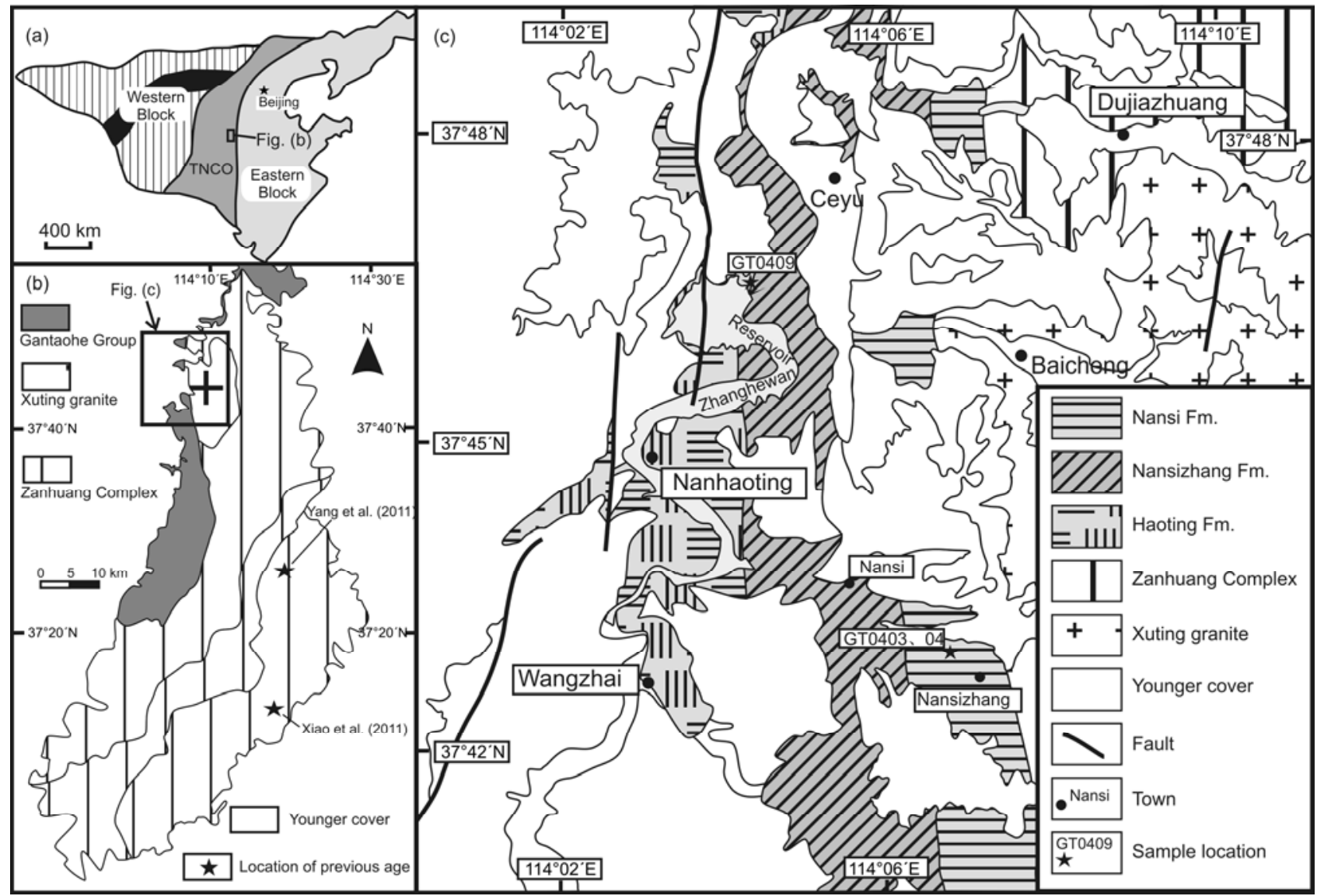

Figure 1 Geological map of the Gantaohe Group occurrence. (a) Tectonic subdivision of the NCC after [12]; (b) relationship between the Gantaohe Group, Zanhuang Complex, and the Xuting Granite (modified after [37]), and three units of the Zanhuang Complex are suggested by [37]; (c) geological map of our research area (based on the 1:50000 Geological Map of the Ceyu area). Also shown in (c) are sample locations. 

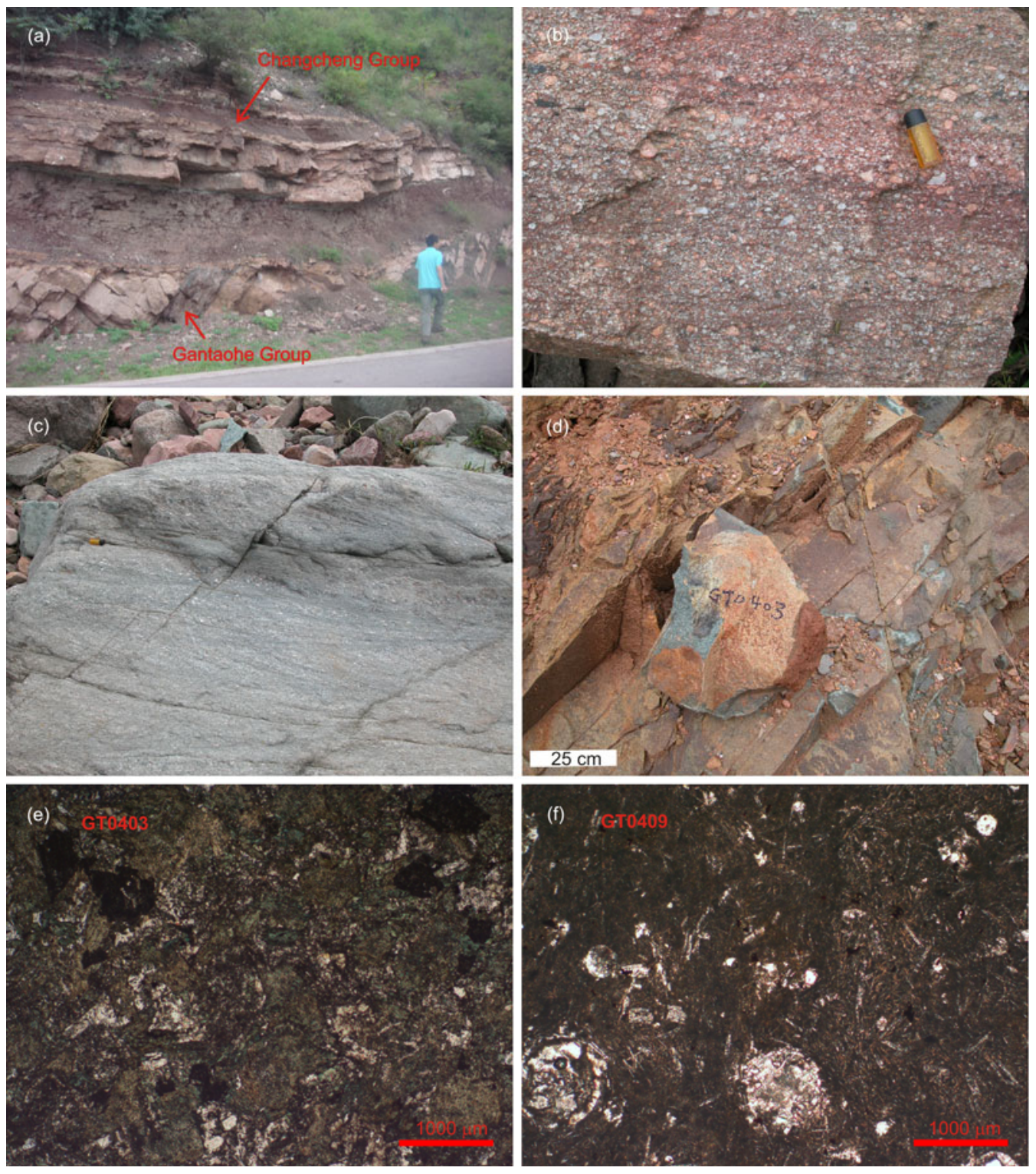

Figure 2 Field photographs and photomicrographs of Gantaohe Group rocks. (a) The Gantaohe Group is discordantly overlain by the Changcheng Group; (b) conglomerate at the base of the Gantaohe Group; (c) feldspathic sandstone of the Gantaohe Group with cross-bedding; (d) basalt sample GT0403; (e) photomicrograph of basalt sample GT0403; (f) photomicrograph of basaltic andesite sample GT0409 showing variolitic texture. Scale in (b) and (c) is ca. 5-cm-long pen cap.

sandstone, are well preserved in some outcrops and were used to determine stratigraphic way-up directions (Figure 2(b), (c)).

Samples were taken along the sections where the Nansizhang and Haoting Formations were named. Basalt samples GT0403 and GT0404 come from a road cut on the road from Nansi to Nansizhang $\left(37^{\circ} 42.98^{\prime} \mathrm{N}, 114^{\circ} 06.72^{\prime} \mathrm{E}\right)$, where the first layer of basaltic lava occurs in the Nansizhang Formation. The rocks show a massive structure (Figure 2(d)), intergranular-intersertal texture and consists of clinoproxene $(\sim 50 \%)$, plagioclase $(\sim 40 \%)$, minor opaque minerals $(5 \%-$ $10 \%)$, quartz $(<5 \%)$, and amphibole. Clinoyroxene and plagioclase are strongly chloritized or epidotized (Figure 2(e)), respectively. Basaltic andesite sample GT0409 was taken from the lower part of the Haoting Formation near the Zhanghewan Reservoir $\left(37^{\circ} 46.36^{\prime} \mathrm{N}, 114^{\circ} 04.41^{\prime} \mathrm{E}\right)$. It shows variolitic texture with most varioles ca. $1 \mathrm{~mm}$ in diameter (Figure 2(f)). The varioles are variable in composition and are dominated by clinopyroxene, plagioclase, or vitreous material and minor quartz. The matrix shows an intersertal texture, and cryptocrystalline clinopyroxenes and devitrified volcanic glass occur together with prismatic plagioclase.

\section{Analytical techniques}

Major elements were analyzed in the National Research Center of Geoanalysis, Chinese Academy of Geological 
Sciences, by XRF on fused glass beads with a precision of better than $1 \%$. Trace elements were determined by an ELEMENT ICP-MS in the Institute of Geology and Geophysics, Chinese Academy of Sciences. Strong acids in sealed teflon bombs were used to digest the samples, and Indium was used as internal standard. The precision is better than 5\%. International standards BCR-2 and AGV-1 were used to monitor the analysis and the results suggest that the RSD (relative standard deviation) was better than 5\% and RE (relative error) was better than $10 \%$.

$\mathrm{Sm}-\mathrm{Nd}$ isotopes were analyzed on a $\mathrm{Nu}$ Plasam HR MC-ICP-MS in the Institute of Geology, Chinese Academy of Geological Sciences. Nd isotopic separation was calibrated using ${ }^{146} \mathrm{Nd} /{ }^{144} \mathrm{Nd}=0.7219$, and the standard JMS was used to monitor precision. Instrumental conditions and the method of separation are described in [23,24].

Zircon dating was carried out using the SHRIMP II instrument in the Beijing SHRIMP Center, Chinese Academy of Geological Sciences. Zircons were separated and concentrated using standard techniques and were then handpicked. The zircons were mounted along with grains of the standard TEM. Zircons without cracks, inclusions and with homogeneous internal textures as monitored by cathodoluminescence (CL) were chosen for analysis. Zircon standard SL 13 (572 Ma, U=238 ppm) was used as a reference to determine the $\mathrm{U}$, Th and $\mathrm{Pb}$ concentrations in the zircons, and zircon standard TEM (417 Ma) was used to calibrate $\mathrm{Pb} / \mathrm{U}$ ratios. Common $\mathrm{Pb}$ was corrected by using the measured ${ }^{204} \mathrm{~Pb}$. Details on SHRIMP II and operating techniques were described in $[25,26]$. Mass resolutions were approximately 5000 (1\% definition). Each analytical site was ras- tered for $3 \mathrm{~min}$ prior to analysis, and five scans through the mass stations were made for each analysis. Errors for individual analyses shown in Table 1 are $1-\sigma$, whereas pooled ages are given with 2- $\sigma$ errors. Data processing used the SQUID and ISOPLOT programs [27,28]. All ages reported here are based on ${ }^{207} \mathrm{~Pb} /{ }^{206} \mathrm{~Pb}$ ratios because these are most precise for rocks older than ca. $1 \mathrm{Ga}$ [29].

The Hf-in-zircon isotopic analyses were conducted on a LA-ICP-MS in the Institute of Geology and Geophysics, Chinese Academy of Sciences. Zircon standards 91500 and GJ-1 were analyzed to monitor precision. The detailed analytical techniques are explained in $\mathrm{Xu}$ et al. [30]. $\varepsilon_{\mathrm{Hf}}(t)$ values are based on a decay constant of ${ }^{176} \mathrm{Lu}\left(\lambda^{176} \mathrm{Lu}=\right.$ $\left.1.865 \pm 0.015 \times 10^{-11} \mathrm{a}^{-1}\right)$ as recommended by Scherer et al. [31], and on the chondritic isotopic ratios $\left({ }^{176} \mathrm{Hf} /{ }^{177} \mathrm{Hf}=\right.$ $0.282772,{ }^{176} \mathrm{Lu} /{ }^{177} \mathrm{Hf}=0.0332$ ) suggested by Blichert-Toft and Albarède [32]. The isotopic ratios of Vervoort and Blichert-Toft [33] for the depleted mantle $\left({ }^{176} \mathrm{Hf} /{ }^{177} \mathrm{Hf}=\right.$ $0.28325,{ }^{176} \mathrm{Lu} /{ }^{177} \mathrm{Hf}=0.0384$ ) were used for depleted mantle model age calculation.

\section{Results}

\subsection{Geochemistry}

The chemical compositions of two basalt samples of the Nansizhang Formation (GT0403 and GT0404) are shown in Table 2. They show flat REE patterns with $\mathrm{La}_{N} / \mathrm{Yb}_{\mathrm{N}}=1.59$ to 1.61 (Figure 3(a), Table 2). No distinct anomaly of $\mathrm{Nb}$, Ta, $\mathrm{Zr}$, or Hf was observed in a trace element variation diagram (Figure $3(\mathrm{~b})$ ). The $f_{\mathrm{Sm} / \mathrm{Nd}}$ value of the two samples is close to

Table 1 The SHRIMP zircon U-Pb data of the rocks in the Gantaohe Group ${ }^{\text {a) }}$

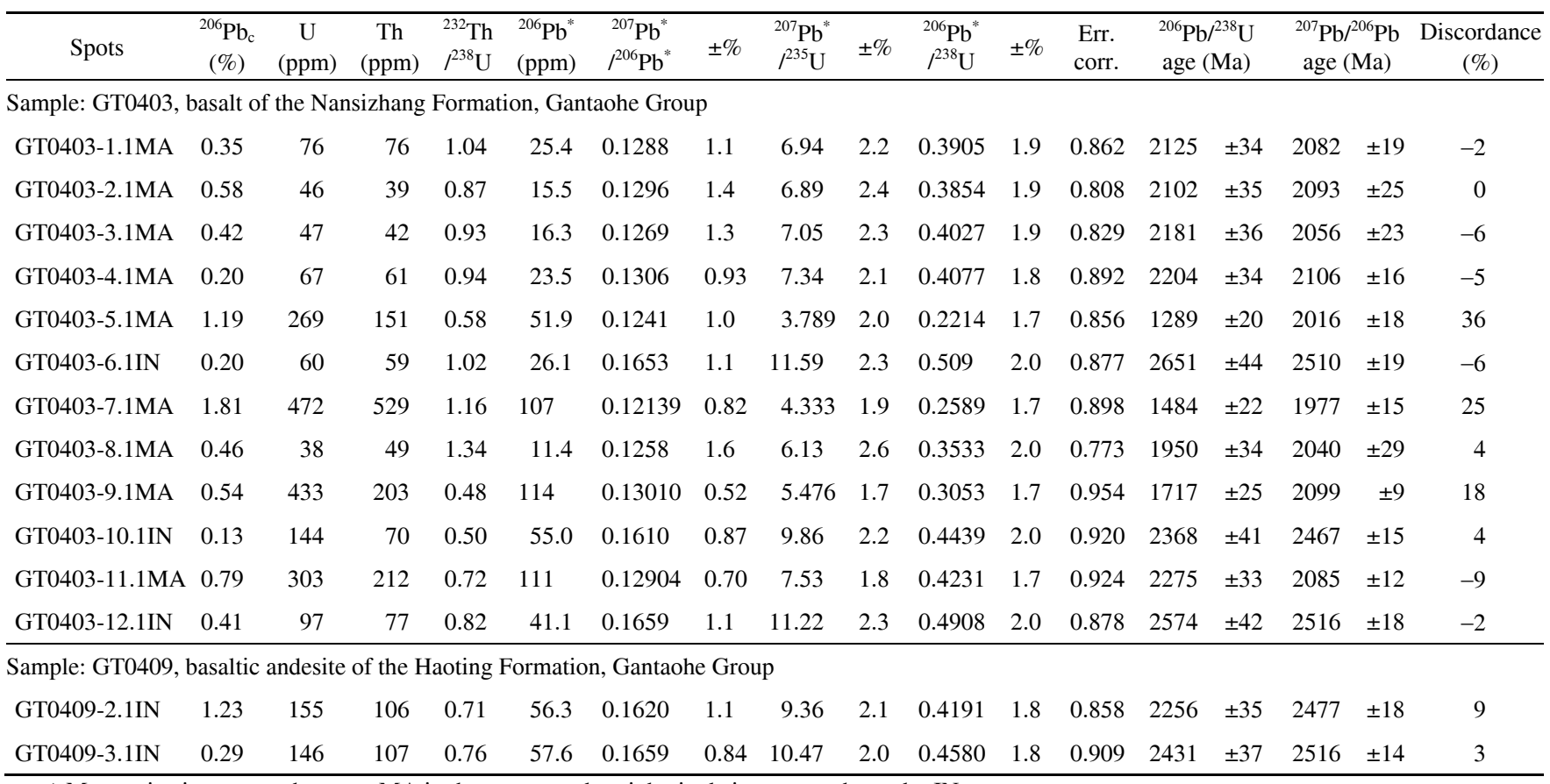

a) Magmatic zircons are shown as MA in the spots number, inherited zircons are shown by IN. 
Table 2 Major (\%) and trace element (ppm) composition of the mafic volcanic rocks in the Gantaohe Group ${ }^{\text {a) }}$

\begin{tabular}{|c|c|c|c|c|}
\hline \multirow{2}{*}{ Composition } & GT0403 & GT0404 & GT0409 & GT0409p \\
\hline & Basalt & Basalt & $\begin{array}{l}\text { Basaltic } \\
\text { andesite }\end{array}$ & $\begin{array}{l}\text { Basaltic } \\
\text { andesite }\end{array}$ \\
\hline $\mathrm{SiO}_{2}$ & 49.22 & 48.80 & 53.57 & \\
\hline $\mathrm{TiO}_{2}$ & 1.36 & 1.46 & 0.66 & \\
\hline $\mathrm{Al}_{2} \mathrm{O}_{3}$ & 13.06 & 13.00 & 14.01 & \\
\hline $\mathrm{Fe}_{2} \mathrm{O}_{3}$ & 4.99 & 5.85 & 4.03 & \\
\hline $\mathrm{FeO}$ & 9.00 & 8.96 & 5.01 & \\
\hline $\mathrm{MnO}$ & 0.23 & 0.23 & 0.15 & \\
\hline $\mathrm{MgO}$ & 6.35 & 6.13 & 7.35 & \\
\hline $\mathrm{CaO}$ & 10.27 & 9.66 & 8.31 & \\
\hline $\mathrm{Na}_{2} \mathrm{O}$ & 1.79 & 2.01 & 2.30 & \\
\hline $\mathrm{K}_{2} \mathrm{O}$ & 0.35 & 0.46 & 0.83 & \\
\hline $\mathrm{P}_{2} \mathrm{O}_{5}$ & 0.12 & 0.12 & 0.11 & \\
\hline $\mathrm{CO}_{2}$ & 0.34 & 0.09 & 0.69 & \\
\hline $\mathrm{H}_{2} \mathrm{O}$ & 2.42 & 2.80 & 3.26 & \\
\hline LOI & 1.70 & 1.79 & 3.23 & \\
\hline Total & 99.50 & 99.57 & 100.28 & \\
\hline $\mathrm{Li}$ & 6.4 & 8.5 & 23.7 & 24.2 \\
\hline $\mathrm{Be}$ & 0.54 & 0.62 & 0.47 & 0.48 \\
\hline $\mathrm{Sc}$ & 49 & 50 & 31 & 31 \\
\hline V & 366 & 386 & 180 & 182 \\
\hline $\mathrm{Cr}$ & 49 & 44 & 136 & 139 \\
\hline Co & 52 & 51 & 45 & 45 \\
\hline $\mathrm{Ni}$ & 39 & 41 & 118 & 119 \\
\hline $\mathrm{Cu}$ & 76 & 77 & 111 & 107 \\
\hline $\mathrm{Zn}$ & 99 & 113 & 72 & 72 \\
\hline $\mathrm{Ga}$ & 18 & 18 & 16 & 17 \\
\hline $\mathrm{Rb}$ & 8 & 12 & 8 & 8 \\
\hline $\mathrm{Sr}$ & 199 & 189 & 283 & 289 \\
\hline Y & 27 & 28 & 15 & 15 \\
\hline $\mathrm{Zr}$ & 92 & 90 & 59 & 60 \\
\hline $\mathrm{Nb}$ & 5.0 & 4.9 & 2.7 & 2.7 \\
\hline Cs & 0.09 & 0.15 & 0.12 & 0.11 \\
\hline $\mathrm{Ba}$ & 367 & 104 & 134 & 135 \\
\hline $\mathrm{La}$ & 6.10 & 6.45 & 8.48 & 8.6 \\
\hline $\mathrm{Ce}$ & 15.00 & 15.09 & 18.25 & 18.78 \\
\hline $\operatorname{Pr}$ & 2.42 & 2.50 & 2.69 & 2.78 \\
\hline $\mathrm{Nd}$ & 11.31 & 11.59 & 11.04 & 11.29 \\
\hline $\mathrm{Sm}$ & 3.41 & 3.59 & 2.63 & 2.63 \\
\hline $\mathrm{Eu}$ & 1.25 & 1.26 & 0.94 & 0.97 \\
\hline $\mathrm{Gd}$ & 4.30 & 4.36 & 2.55 & 2.60 \\
\hline $\mathrm{Tb}$ & 0.74 & 0.78 & 0.43 & 0.44 \\
\hline Dy & 4.95 & 5.07 & 2.76 & 2.77 \\
\hline Ho & 1.08 & 1.10 & 0.57 & 0.58 \\
\hline $\mathrm{Er}$ & 2.89 & 3.02 & 1.64 & 1.63 \\
\hline $\mathrm{Tm}$ & 0.44 & 0.45 & 0.25 & 0.26 \\
\hline $\mathrm{Yb}$ & 2.74 & 2.87 & 1.59 & 1.59 \\
\hline $\mathrm{Lu}$ & 0.43 & 0.43 & 0.25 & 0.24 \\
\hline $\mathrm{Hf}$ & 2.7 & 2.7 & 1.6 & 1.7 \\
\hline $\mathrm{Ta}$ & 0.33 & 0.32 & 0.16 & 0.16 \\
\hline $\mathrm{Tl}$ & 0.05 & 0.07 & 0.05 & 0.05 \\
\hline $\mathrm{Pb}$ & 107.6 & 41.6 & 39.4 & 37.9 \\
\hline $\mathrm{Bi}$ & 0.04 & 0.05 & 0.02 & 0.02 \\
\hline Th & 0.7 & 0.7 & 0.4 & 0.34 \\
\hline U & 0.16 & 0.17 & 0.06 & 0.07 \\
\hline
\end{tabular}
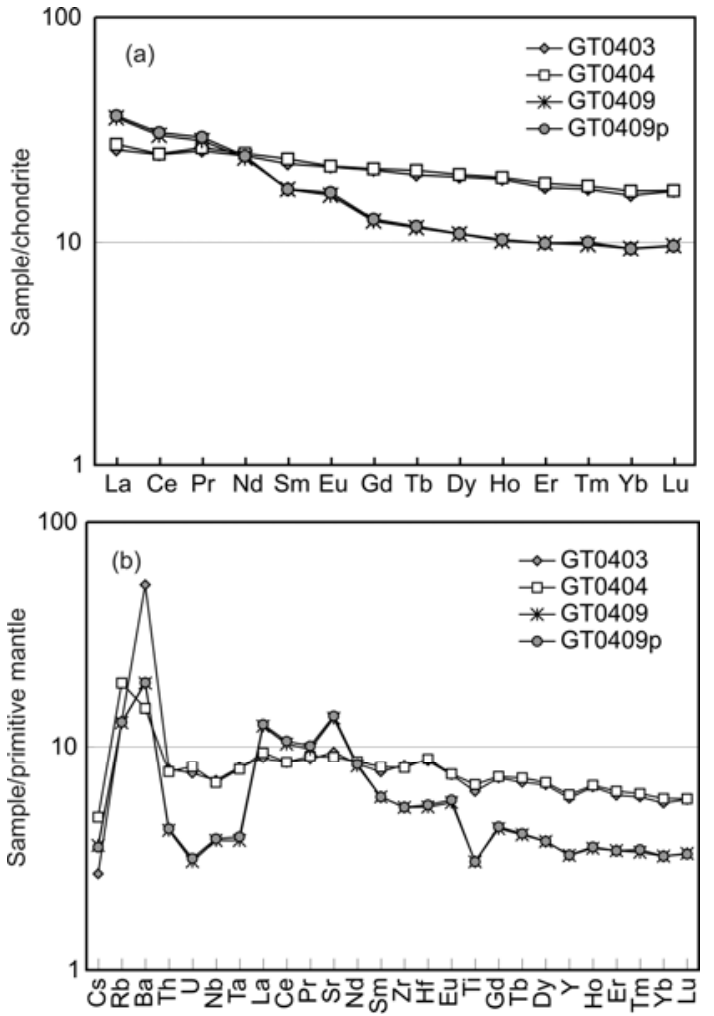

Figure 3 Chondrite-normalized REE patterns (a) and primitive mantlenormalized trace element variation diagram (b) for mafic volcanic rocks of the Gantaohe Group. Normalizing values after Sun and McDonough [34].

zero $(-0.07$ and -0.09$)$, suggesting that fractionation between $\mathrm{Sm}$ and $\mathrm{Nd}$ is negligible and, therefore, the chemistry of these samples retains features of their magmatic source. The two samples have high $\varepsilon_{\mathrm{Nd}}(t)$ values of +4.0 and +2.7 (Table 3), and depleted mantle Nd model ages of 2.42 and $2.78 \mathrm{Ga}$.

A sample of the Haoting Formation (GT0409, basaltic andesite, see Table 2) shows more obvious fractionation of REE with $(\mathrm{La} / \mathrm{Yb})_{\mathrm{N}}$ being 3.83 to 3.91 (duplicate analyses, Figure 3(a)). It shows clear negative anomalies of $\mathrm{Nb}$ and Ta when compared with La, but not when compared with Th (Figure 3(b)). No distinct negative anomaly of $\mathrm{Zr}$ or $\mathrm{Hf}$ is observed (Figure 3(b)). The rock has a low $\varepsilon_{\mathrm{Nd}}(t)$ value of -0.8 and a depleted mantle $\mathrm{Nd}$ model age of $2.75 \mathrm{Ga}$ (Table 3 ).

\subsection{SHRIMP zircon dating}

Two samples (GT0403 and GT0409) were dated, and the zircons are mostly prismatic, with length to width ratios of $1: 1$ to $1: 2$. Most zircons are small, and the length varies from 50 to $100 \mu \mathrm{m}$ (Figure 4). Two zircon types were identified according to shape and internal structure. Type I zircons are automorphic and show broadly-spaced zoning in CL images, similar to magmatic zircons from intermediate to mafic magmatic rocks (e.g. 1.1 MA and 2.1 MA in Figure 4(a), 11.1MA in Figure 4(b)). Type I zircons were only 
Table 3 Whole-rock Nd isotopic data for mafic volcanic rocks of the Gantaohe Group

\begin{tabular}{ccccccccccc}
\hline Sample No. & Lithology & $\mathrm{Sm}(\mathrm{ppm})$ & $\mathrm{Nd}(\mathrm{ppm})$ & ${ }^{147} \mathrm{Sm} /{ }^{144} \mathrm{Nd}$ & ${ }^{143} \mathrm{Nd} /{ }^{144} \mathrm{Nd}$ & $2 \sigma$ & $T_{\mathrm{DM}}(\mathrm{Ma})$ & $\varepsilon_{\mathrm{Nd}}(0)$ & $\varepsilon_{\mathrm{Nd}}(t=2083 \mathrm{Ma})$ & $f_{\mathrm{Sm} / \mathrm{Nd}}$ \\
\hline GT0403 & basalt & 2.982 & 10.071 & 0.1791 & 0.512599 & 10 & 2416 & -0.8 & 4.0 & -0.09 \\
GT0404 & basalt & 3.359 & 11.072 & 0.1835 & 0.512597 & 5 & 2775 & -0.8 & 2.7 & -0.07 \\
GT0409 & basaltic andesite & 2.302 & 9.806 & 0.142 & 0.511849 & 12 & 2750 & -15.4 & -0.8 & -0.28 \\
\hline
\end{tabular}

observed in sample GT0403. Type II zircons are also automorphic but show variously rounded terminations. More importantly, they show oscillatory zoning in CL images (e.g. 6.1IN in Figure 4(a), 12.1IN in Figure 4(b)), a feature typical of zircons found in granitoid rocks. Type II zircons occur in both samples.

The 12 analyses were made on 12 zircons from Nansizhang basalt sample GT0403 (Figure 5(a), Table 1). The 9 analyses of type I magmatic zircons yielded ${ }^{207} \mathrm{~Pb} /{ }^{206} \mathrm{~Pb}$ ages between 1977 and 2106 Ma. Excluding analyses 5.1 and 7.1, the remainder yielded a weighted mean ${ }^{207} \mathrm{~Pb} /{ }^{206} \mathrm{~Pb}$ age of $2090 \pm 11 \mathrm{Ma}(\mathrm{MSWD}=1.3)$. If only five near-concordant analyses are considered, the weighted mean ${ }^{207} \mathrm{~Pb} /{ }^{206} \mathrm{~Pb}$ age is $2087 \pm 16 \mathrm{Ma}(\mathrm{MSWD}=1.3$ ) which is interpreted as the crystallization age of the basalt. Although abundant xenocrystic zircons of type II occur in the sample, only 3 analyses were carried out, yielding older ${ }^{207} \mathrm{~Pb} /{ }^{206} \mathrm{~Pb}$ age with 2467 to $2516 \mathrm{Ma}$.

Only two analyses were made on zircons of sample GT0409, the analyzed zircons are both xenocryst and the ${ }^{207} \mathrm{~Pb} /{ }^{206} \mathrm{~Pb}$ ages are $2477 \pm 18 \mathrm{Ma}$ and $2516 \pm 14 \mathrm{Ma}$, respectively (Figure 5(b), Table 1).

\subsection{Hf-in-zircon isotopic data}

Ten zircons in sample GT0403 were chosen for Hf isotopic analyses (Figure 6, Table 4). Eight analyses were placed on top of the SHRIMP analytical sites, including 6 magmatic
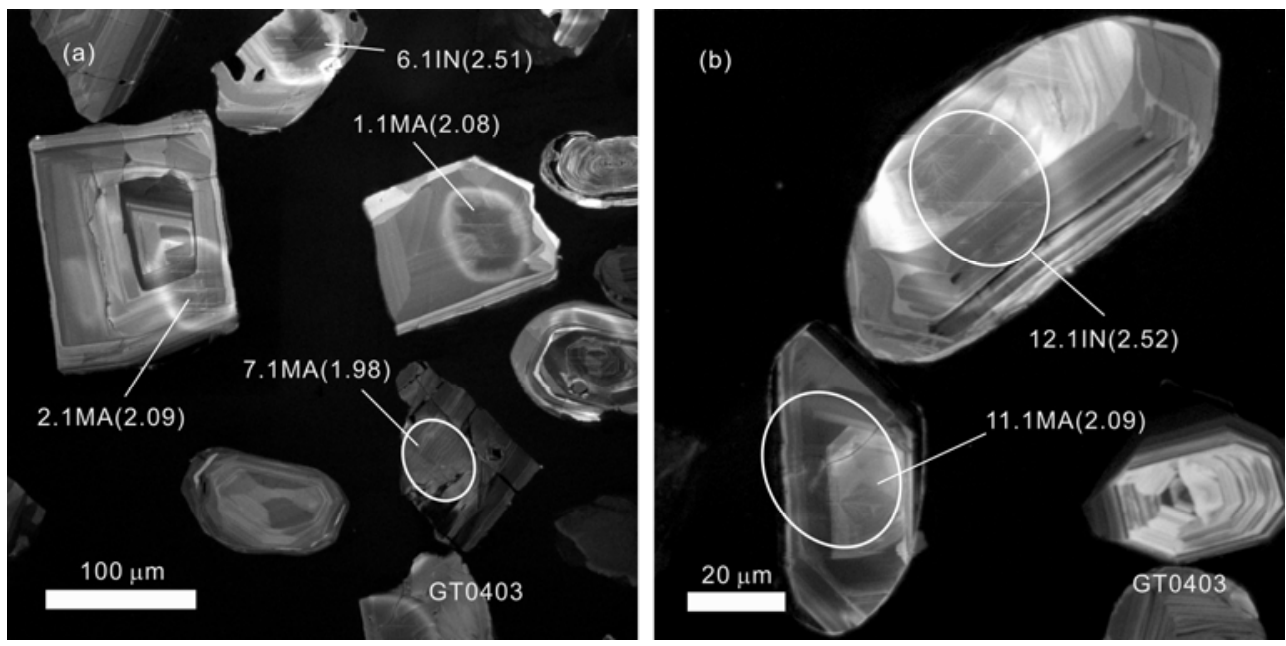

Figure 4 Representative CL images of zircons from basalt sample GT0403. Also shown are the SHRIMP analytical spots and ${ }^{207} \mathrm{~Pb} /{ }^{206} \mathrm{~Pb}$ ages $(\mathrm{Ga})$.
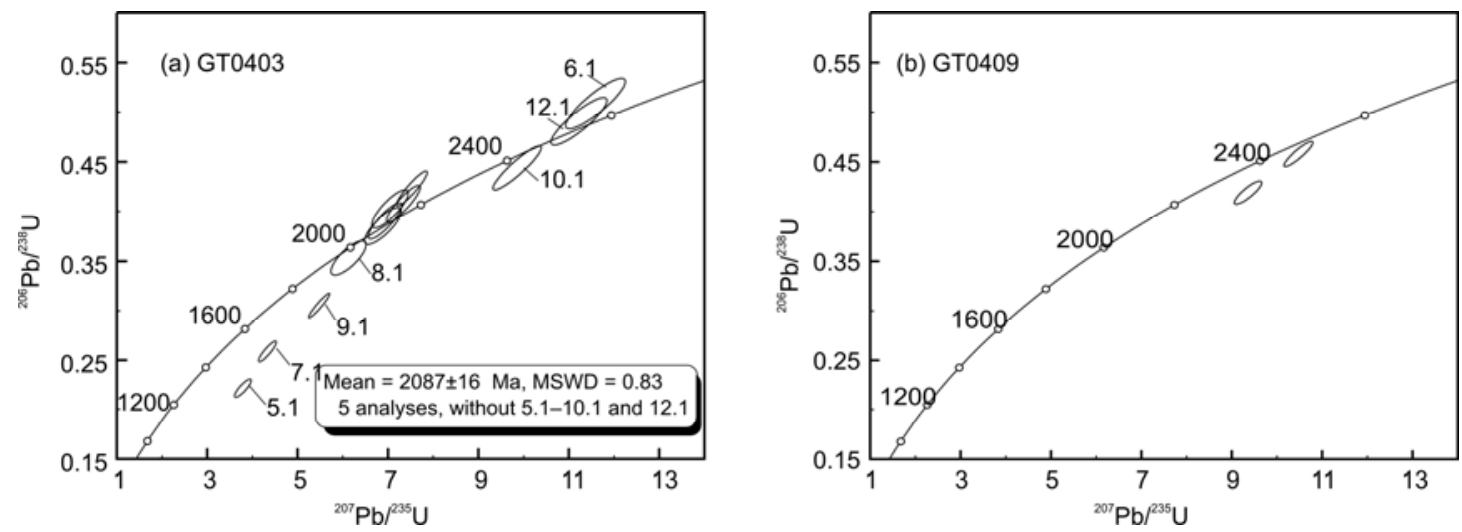

Figure 5 Concordia diagrams showing SHRIMP zircon analyses from mafic volcanic rocks of the Gantaohe Group. (a) Basalt sample GT0403; (b) basaltic andesite sample GT0409. Error ellipses are $1-\sigma$. 


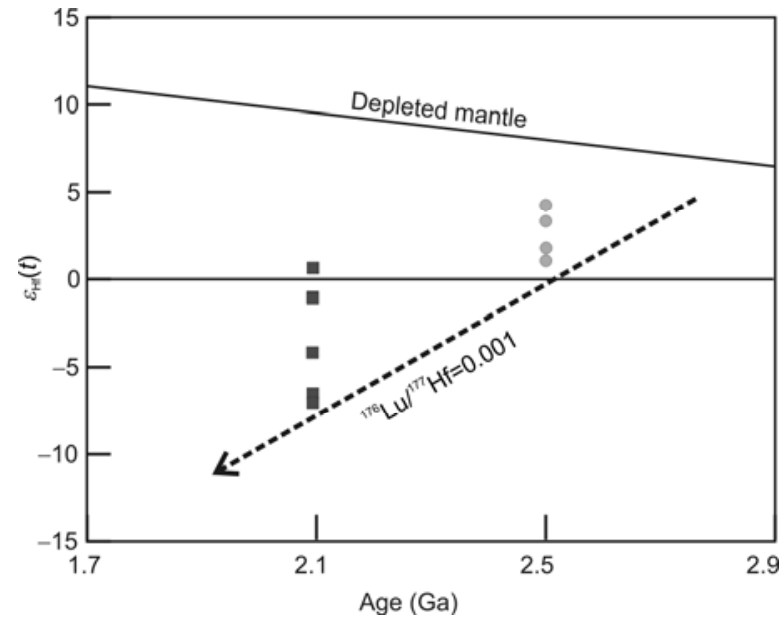

Figure 6 Age versus $\varepsilon_{\mathrm{Hf}}(t)$ diagram for zircons from basalt sample GT0403. Squares are igneous zircons and circles are xenocrysts. The average zircon ${ }^{176} \mathrm{Lu} /{ }^{177} \mathrm{Hf}$ ratio of 0.001 was adopted to calculate Hf-evolution line (dotted line).

zircons and two xenocrystic zircons, and the other two analyses should be on ca. $2.5 \mathrm{Ga}$ xenocrystic zircons in terms of the internal structures of zircons in CL images. Six magmatic zircons yielded varying $\varepsilon_{\mathrm{Hf}}(t=2087 \mathrm{Ma})$ values of -7.21 to 0.47 , and the four xenocrysts show positive $\varepsilon_{\mathrm{Hf}}(t=$ $2500 \mathrm{Ma}$ ) values from 1.01 to 4.35 . The xenocrystic zircons have similar $\varepsilon_{\mathrm{Hf}}(t=2087 \mathrm{Ma})$ values as the minimum value for the magmatic zircons (-7.21), varying from -4.91 to -8.2 .

\section{Discussion}

SHRIMP zircon dating of a basaltic volcanic rock of the Nansizhang Formation yielded an emplacement age of 2087 $\pm 16 \mathrm{Ma}$, suggesting that the Gantaohe Group formed in the middle Paleoproterozoic. The Zanhuang Complex, generally interpreted as the metamorphic basement of the Gantaohe Group, experienced upper amphibolite- to granulite-facies metamorphism at ca. $1.82 \mathrm{Ga}[35,36]$. This is incompatible with the low-grade metamorphism of the Paleoproterozoic Gantaohe Group. However, these high grade metamorphic rocks of the Zanhuang Complex are located in its southeastern part, far from our study area (Figure 1(b)). Large-scale ductile shear zones were identified in the Zanhuang Complex [37], and Yang et al. (unpublished data). Moreover, no ca.1.8 Ga metamorphic zircon age has so far been found in the ca. $2.5 \mathrm{Ga}$ Jiandeng granite which is also located in the southeastern part of the Zanhuang Complex [38]. These differences suggest that the Zanhuang Complex consists of different tectonic units. In addition the ca. 2.1 Ga Xuting granite to the east of the Gantaohe Group did not experience high-grade metamorphism and deformation [39], which also suggests that metamorphism in our study area is different from the southeastern part of the Zanhuang Complex.

The Gantaohe Group rocks were deposited on continental crust, and contamination with older crust played an important role during formation of the mafic volcanic rocks. This is supported by the following evidence: (1) widespread conglomerates with granitoid gneiss pebbles and feldspathic sandstone occur at the base of the Gantaohe Group; (2) the basaltic rocks (GT0403 and GT0404) have no negative $\mathrm{Nb}$ and Ta anomalies and have high $\varepsilon_{\mathrm{Nd}}(t)$ values of 4.0 to 2.7, whereas the relatively felsic rock (GT0409) has significant negative $\mathrm{Nb}$ and $\mathrm{Ta}$ anomalies and a low $\varepsilon_{\mathrm{Nd}}(t)$ value of -0.8 ; (3) abundant ca. $2.5 \mathrm{Ga}$ xenocrystic zircons occur in the dated rock which are considered to be derived from the Zanhuang Complex, for instance from the widespread ca. 2.5 Ga granitoids (e.g. Jiandeng Granitoid [38]); and (4) zircons in sample GT0403 have variable $\varepsilon_{\mathrm{Hf}}(t)$ values with some being negative.

It would appear that the $\mathrm{Hf}-\mathrm{Nd}$ isotopes in sample GT0403 are decoupled. The zircon $\varepsilon_{\mathrm{Hf}}(t)$ values are mostly

Table 4 Lu-Hf data for zircons of basalt sample GT0403 of the Nansizhang Formation ${ }^{\text {a) }}$

\begin{tabular}{|c|c|c|c|c|c|c|c|c|c|c|c|c|}
\hline Analysis No. & $\begin{array}{c}\text { Corresponding } \\
\text { SHRIMP } \\
\text { dating number }\end{array}$ & $\begin{array}{c}{ }^{207} \mathrm{~Pb} /{ }^{206} \mathrm{~Pb} \\
\text { age }\end{array}$ & ${ }^{176} \mathrm{Yb} /{ }^{177} \mathrm{Hf}$ & ${ }^{176} \mathrm{Lu} /{ }^{177} \mathrm{Hf}$ & $\begin{array}{c}{ }^{176} \mathrm{Hf} /{ }^{177} \mathrm{Hf} \\
\text { (corr) }\end{array}$ & $2 \sigma_{\mathrm{m}}$ & $\varepsilon_{\mathrm{Hf}}(0)$ & $\begin{array}{c}\varepsilon_{\mathrm{Hf}}(t= \\
2087 \mathrm{Ma})\end{array}$ & $\begin{array}{c}\varepsilon_{\mathrm{Hf}}(t= \\
2500 \mathrm{Ma})\end{array}$ & $2 \sigma$ & $t_{\mathrm{DM}}(\mathrm{Hf})$ & $f_{\mathrm{Lu} / \mathrm{Hf}}$ \\
\hline GT0403-01 & $1.1 \mathrm{MA}$ & 2082 & 0.0289 & 0.0007 & 0.281497 & 0.000038 & -45.10 & 0.47 & & 1.34 & 2435 & -0.98 \\
\hline GT0403-02 & $2.1 \mathrm{MA}$ & 2093 & 0.0313 & 0.0008 & 0.281466 & 0.000040 & -46.18 & -0.81 & & 1.44 & 2486 & -0.97 \\
\hline GT0403-03 & $3.1 \mathrm{MA}$ & 2056 & 0.0370 & 0.0010 & 0.281472 & 0.000041 & -45.97 & -0.82 & & 1.44 & 2487 & -0.97 \\
\hline GT0403-04 & 4.1MA & 2106 & 0.0377 & 0.0009 & 0.281377 & 0.000039 & -49.33 & -4.09 & & 1.38 & 2613 & -0.97 \\
\hline GT0403-05 & $6.1 \mathrm{IN}$ & 2510 & 0.0234 & 0.0007 & 0.281248 & 0.000045 & -53.89 & -8.37 & 1.01 & 1.59 & 2772 & -0.98 \\
\hline GT0403-06 & $5.1 \mathrm{MA}$ & 2016 & 0.0327 & 0.0009 & 0.281305 & 0.000052 & -51.88 & -6.69 & & 1.83 & 2712 & -0.97 \\
\hline GT0403-07 & & $2500^{*}$ & 0.0185 & 0.0006 & 0.281261 & 0.000044 & -53.42 & -7.67 & 1.71 & 1.56 & 2743 & -0.98 \\
\hline GT0403-08 & $12.1 \mathrm{IN}$ & 2516 & 0.0518 & 0.0017 & 0.281357 & 0.000034 & -50.05 & -5.85 & 3.26 & 1.21 & 2691 & -0.95 \\
\hline GT0403-09 & $11.1 \mathrm{MA}$ & 2085 & 0.1201 & 0.0039 & 0.281409 & 0.000039 & -48.21 & -7.21 & & 1.40 & 2788 & -0.88 \\
\hline GT0403-10 & & $2500 *$ & 0.0234 & 0.0008 & 0.281348 & 0.000039 & -50.36 & -5.00 & 4.35 & 1.39 & 2646 & -0.97 \\
\hline
\end{tabular}

a) * in the ${ }^{207} \mathrm{~Pb} /{ }^{206} \mathrm{~Pb}$ age column means the age was inferred according to the characteristics of the CL images. 
negative, from -7.21 to 0.47 , but the $\varepsilon_{\mathrm{Nd}}(t)$ value of the whole-rock is distinctly positive at 4.0. This may be due to the fact that the Hf isotopes record the local isotopic characteristics of the magmatic zircons, whereas the whole-rock $\mathrm{Nd}$ isotopes record the bulk isotopic composition when the magma solidifies. Large difference may occur between the two isotopic compositions in the following case. Emplecement of primitive basaltic magma derived from a depleted mantle source will lead to melting of continental rocks during magmatic underplating and/or magma ascent because of its high temperature. At the contact zone, the magma will become contaminated with crustal material which favors the formation of magmatic zircons because of the relatively high silica and zirconium content of the contaminated melt. The $\varepsilon_{\mathrm{Hf}}(t)$ values of our magmatic zircons in the Nansizhang basalt are highly variable, and some are distinct negative, typical of crust-mantle interaction. Subsequently, the contaminated magma mixed with new basaltic magma derived from the depleted mantle source. The rock ultimately formed from the mixed magma exhibits the depleted mantle $\mathrm{Nd}$ isotopic characteristics with a strongly positive $\varepsilon_{\mathrm{Nd}}(t)$ value. In sample GT0403, the ca. $2.5 \mathrm{Ga}$ inherited zircons have similar $\varepsilon_{\mathrm{Hf}}(t=2.09 \mathrm{Ga})$ values as the lowest value of magmatic zircons (-7.17). This may suggest that some magmatic zircons record the Hf isotopic characteristics of the crustal melt, implying that some magmatic zircons formed at the beginning of crustal contamination so that they kept their inherited crustal isotopic characteristics.

The alkaline elements are low in all samples, plot in the sub-alkaline filed in the $\mathrm{Na}_{2} \mathrm{O}+\mathrm{K}_{2} \mathrm{O}-\mathrm{SiO}_{2}$ diagram (Figure 7(a)), and show a pronounced trend towards iron enrichment in the AFM diagram (Figure 7(b)), typical of tholeiites. Samples GT0403 and GT0404 of the Nansizhang Formation show weak REE fractionation and no obvious negative anomalies in $\mathrm{Nb}, \mathrm{Ta}, \mathrm{Zr}$ and $\mathrm{Hf}$ and are thus distinctly different from island arc or continental arc basalts. Sample GT0409 of the Haoting Formation shows negative anomalies in $\mathrm{Nb}$ and $\mathrm{Ta}$ but no negative anomalies in $\mathrm{Zr}$ and $\mathrm{Hf}$ and is therefore also different from arc volcanic rocks but similar to within-plate basalts. In the Th-Hf-Nb diagram [40], all samples plot near the boundary between the within-plate basalt field and N-MORB field, consistent with the intracontinental environment (Figure 7(c)). The Xuting granite near the Gantaohe Group has a SHRIMP zircon age of $2090 \pm 10 \mathrm{Ma}$ which is identical to our age of the Nansizhang basalt. This granite shows geochemical features of A-type granites formed in a within-plate rift environment [39]. We consider the Xuting granite and the intermediate to mafic volcanic rocks of the Gantaohe Group to reflect bimodal magmatism at ca. $2.1 \mathrm{Ga}$, and, according to the rock association and geochemistry, the Gantaohe Group rocks formed above a continental basement, most likely in a continental rift.

Zhao et al. [10-13] divided the NCC into three major tectonic units: the Eastern and Western Blocks and the Trans-North China Orogen (TNCO, also called the Central Belt) between them. They suggested that subduction of the Western Block beneath the Eastern Block began ca. 2.5 Ga ago, and collision between the two blocks resulted in subsequent cratonization of the NCC at ca. 1.80-1.85 Ga. This implies that the Paleoproterozoic rocks in the TNCO formed in an intra-oceanic or active continental margin environment which is not consistent with our results for the Gantaohe Group volcanic rocks.

Apart from the Gantaohe Group discussed here there are several middle Paleoproterozoic supracrustal sequences in the TNCO, such as the Hutuo Group in Wutai, the Lüliang Group and Yejishan Groups in Lüliang, the Zhongtiao and Jiangxian Groups in Zhongtiao, and the Songshan Group in Dengfeng. All these sequences have similar ages to the Gantaohe Group [16,41-54], and there is a serious debate on the depositional environment of these Paleoproterozoic supracrustal sequences. Du et al. [55] suggested that the Hutuo Group formed in a continental environment and pointed out that the geochemistry of Hutuo basalts are different from that of island-arc basalt but similar to that of continental rift basalt [55,56]. Guo et al. [57] also suggested a continental rift environment for the Hutuo Group, based
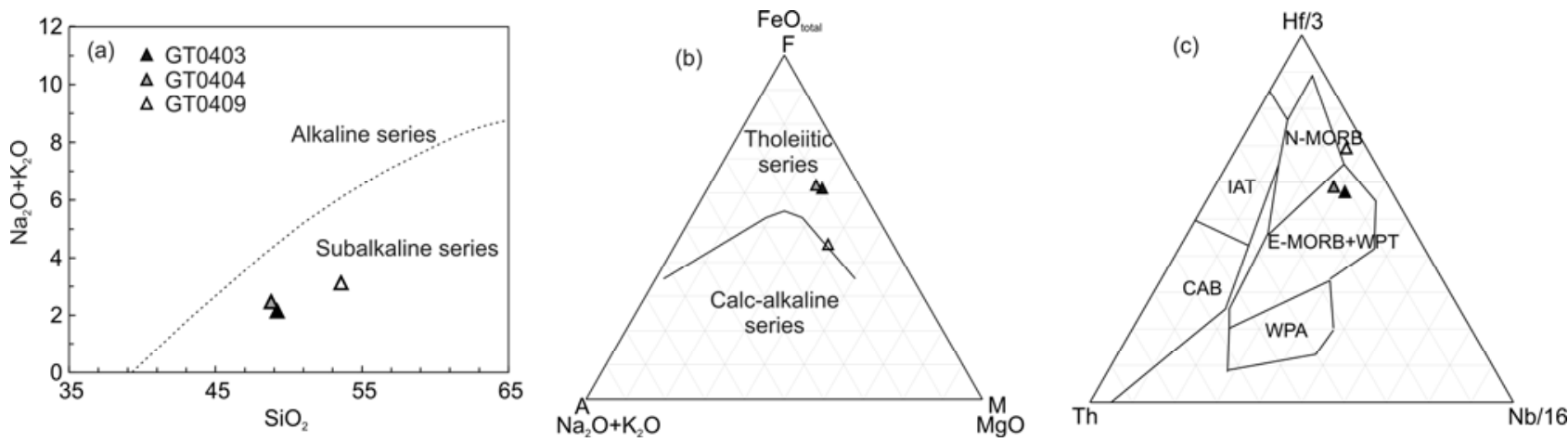

Figure 7 Discrimination diagrams for mafic to intermediate volcanic rocks of the Gantaohe Group. (a) $\mathrm{SiO}_{2}-\left(\mathrm{Na}_{2} \mathrm{O}+\mathrm{K}_{2} \mathrm{O}\right)$ diagram; (b) $\mathrm{AFM}$ ((Na $2 \mathrm{O}+$ $\mathrm{K}_{2} \mathrm{O}$ )-total $\mathrm{FeO}-\mathrm{MgO}$, molecular proportion) diagram; (c) Th-Hf-Nb discrimination diagrams for basalt (after [40]). CAB: calc-alkaline basalt, IAT: islandarc tholeiite, N-MORB: mid-ocean ridge basalt, E-MORB: enriched mid-ocean ridge basalt, WPT: within-plate basalt, WPA: within-plate alkaline basalt. 
on geological relationships, sedimentary association and structural features. However, other researchers considered that the Hutuo Group formed along a continental margin [16]. The volcanic rocks of the Lüliang Group exhibit bimodal features and were suggested to have formed in a continental margin or continental rift environment by $\mathrm{Yu}$ et al. [58] and Geng et al. [59,60]. However, Liu et al. [45,61] suggested that rocks of the Lüliang and Yejiashan Groups formed in a continental arc according to rock association, detrital zircons age spectra and geochemistry. Bimodal volcanic rocks in the Zhongtiao area have apparently evolved in an extensional continental setting as suggested by Sun et al. [50]; Li et al. [49] proposed that the most likely depositional environment for the Jiangxian Group and Zhongtiao Group is a continental margin according to the geochemistry and detrital zircon ages of metasedimentary rocks. In contrast, Liu et al. [47] speculated that the Zhongtiao area constituted an island arc or back-arc environment in the Paleoproterozoic.

We support most of the above conclusions in that these time-equivalent Paleoproterozoic volcano-sedimentary sequences most likely formed in a continental rift environment and that the TNCO and Eastern Block were already a single continental terrane since the end of the Archean. The evidence is as follows: (1) the volcanic rocks in all these Paleoproterozoic sequences show bimodal features with a distinct lack of andesite, a common rock in island-arc terranes; (2) ca. $2.5 \mathrm{Ga}$ xenocrystic zircons occur abundantly in the volcanic rocks and suggest formation on a continental basement; (3) some volcanic rocks lack negative $\mathrm{Nb}$ and Ta anomalies in their trace element chemistry, a typical feature of a subduction environment; and (4) there are abundant 2.5-2.7 Ga granitoids and supracrustal rocks in the basement. We therefore support a continental rift setting for the Paleoproterozoic volcano-sedimentary sequences (including the Gantaohe Group) in the TNCO, similar to the model of $\mathrm{Li}$ et al. [62] and $\mathrm{Li}$ and Zhao [63] to explain the tectonic setting of granitoids and supracrustal rocks in the Jiao-Liao-Ji belt.

\section{Conclusions}

(1) SHRIMP zircon dating suggests that the Gantaohe Group is a Paleoproterozoic $(2.09 \mathrm{Ga})$ volcano-sedimentary sequence.

(2) Crustal contamination affected the formation of volcanic rocks of the Gantaohe Group as indicated by numerous xenocrystic zircons, the whole-rock geochemistry and Hf-in-zircon isotopic data.

(3) Paleoproterozoic volcano-sedimentary sequences in the TNCO exhibit geological and geochemical characteristics of deposition in a continental rift. This implies that the TNCO evolved in a continental environment during the middle Paleoproterozoic and that the TNCO and Eastern
Block were already a single tectonic unit since the end of the Archean.

We would like to thank Yuhai Zhang and Zhiqing Yang for help in SHRIMP dating and Hua Tao, Qing Ye, Hui Zhou and Chun Yang for zircon mount making and CL imaging. We are grateful to Prof. Guochun Zhao and the other two anonymous reviewers for their valuable comments and suggestions. This work was supported by the China Geological Survey (1212010811033) and the National Basic Research Program of China (2012CB416601).

1 Liu D Y, Nutman A P, Compston W, et al. Remnants of $\geqslant 3800 \mathrm{Ma}$ crust in the Chinese part of the Sino-Korean craton. Geology, 1992, 20: $339-342$

2 Wu J S, Geng Y S, Shen Q H, et al. Archaean Geology Characteristics and Tectonic Evolution of China-Korea Paleo-Continent (in Chinese). Beijing: Geological Publishing House, 1998. 212

3 Bai J, Huang X G, Wang H C, et al. The Precambrian Crustal Evolution of China (in Chinese). 2nd ed. Beijing: Geological Publishing House, 1996. 259

4 Zhai M G, Bian A G, Zhao T P. The amalgamation of the supercontinent of North China Craton at the end of Neo-Archaean and its breakup during late Palaeoproterozoic and Meso-Proterozoic. Sci China-Earth Sci, 2000, 43(Suppl): 219-232

5 Zhai M G, Peng P. Paleoproterozoic events in the North China Craton (in Chinese). Acta Petrol Sin, 2007, 23: 2665-2682

6 Kusky T M, Li J. Paleoproterozoic tectonic evolution of the North China Craton. J Asian Earth Sci, 2003, 22: 383-397

7 Li J, Kusky T M. A Late Archean foreland fold and thrust belt in the North China Craton: Implications for early collisional tectonics. Gondwana Res, 2007, 12: 47-66

8 Kusky T M. Geophysical and geological tests of tectonic models of the North China Craton. Gondwana Res, 2011, 20: 26-35

9 Wan Y, Dong C, Liu D, et al. Zircon ages and geochemistry of late Neoarchean syenogranites in the North China Craton: A review. Precambrian Res, 2011, doi: 10.1016/j.precamres.2011.05.001

10 Zhao G, Wilde S A, Cawood P A, et al. Thermal evolution of Archaean basement rocks from the eastern part of the North China Craton and its bearing ontectonic setting. Int Geol Rev, 1998, 40: 706-721

11 Zhao G, Wilde S A, Cawood P A, et al. Archean blocks and their boundaries in the North China Craton: Lithological, geochemical, structural and P-T path constraints and tectonic evolution. Precambrian Res, 2001, 107: 45-73

12 Zhao G, Sun M, Wilde S A, et al. Late Archean to Paleoproterozoic evolution of the North China Craton: Key issues revisited. Precambrian Res, 2005, 136: 177-202

13 Zhao G, Kröner A, Wilde S A, et al. Lithotectonic elements and geological events in the Hengshan-Wutai-Fuping belt: A synthesis and implications for the evolution of the Trans-North China Orogen. Geol Mag, 2007, 144: 753-775

14 Zhao G, Wilde S A, Sun M, et al. SHRIMP U-Pb zircon ages of granitoid rocks in the Lüliang Complex: Implications for the accretion and evolution of the Trans-North China Orogen. Precambrian Res, 2008, 160: 213-226

15 Zhao G, Wilde S A, Guo J, et al. Single zircon grains record two Paleoproterozoic collisional events in the North China Craton. Precambrian Res, 2010, 177: 266-276

16 Wilde S A, Zhao G C, Wang K Y, et al. First SHRIMP zircon U-Pb ages for Hutuo Group in Wutaishan: Further evidence for Palaeoproterozoic amalgamation of North China Craton. Chin Sci Bull, 2004, 49: 83-90

17 Wilde S A, Cawood P A, Wang K, et al. Granitoid evolution in the Late Archean Wutai Complex, North China Craton. J Asian Earth Sci, 2005, 24: 597-613

18 Liu C, Zhao G, Sun M, et al. U-Pb and Hf isotopic study of detrital zircons from the Yejishan Group of the Lüliang Complex: Con- 
straints on the timing of collision between the Eastern and Western Blocks, North China Craton. Sediment Geol, 2011, 236: 129-140

19 Liu S, Zhao G, Wilde S A, et al. Th-U-Pb monazite geochronology of the Lüliang and Wutai Complexes: Constraints on the tectonothermal evolution of the Trans-North China Orogen. Precambrian Res, 2006, 148: 205-224

20 Wang Z, Wilde S A, Wang J. Tectonic setting and significance of 2.3-2.1Ga magmatic events in the Trans-North China Orogen: New constraints from the Yanmenguan mafic-ultramafic intrusion in the Hengshan-Wutai-Fuping area. Precambrian Res, 2010, 178: 27-42

21 Bureau of Geology and Mineral Resources of Hebei Province. Regional Geology of Hebei Province, Beijing Municipality and Tianjin Municipality (in Chinese). Beijing: Geological Publishing House, 1989. 741

22 Wan Y S, Miao P S, Liu D Y, et al. Formation ages and source regions of the Palaeoproterozoic Gaofan, Hutuo and Dongjiao groups in the Wutai and Dongjiao areas of the North China Craton from SHRIMP U-Pb dating of detrital zircons: Resolution of debates over their stratigraphic relationships. Chin Sci Bull, 2010, 55: 1278-1284

23 He X X, Tang S H, Zhu X K, et al. Precise measurement of Nd isotopic ratios by means of multi-collector magnetic sector inductively coupled plasma mass spectrometry (MC-ICPMS) (in Chinese). Acta Geosci Sin, 2007, 28: 405-410

24 Ye X J, Zhang Z Q. Separation of Sm and Nd in the determination of Nd ratio: HDEHP separation method (in Chinese). Chin Anal Bull, 1990, 9: 6-9

25 Williams I S. U-Th- Pb geochronology by ion microprobe. In: Mickibben M A, Shanks III W C, Ridley W I, eds. Applications of Micro Analytical Techniques to Understanding Mineralizing Processes. Rev Econ Geol, 1998, 7: 1-35

26 Liu D Y, Jian P. 243 Ma UHP and 228 Ma retrograde events of the Shuanghe jadeite quartzite, eastern Dabie mountains: SHRIMP dating, mineral inclusions and zircon REE patterns (in Chinese). Acta Geol Sin, 2004, 78: 211-217

27 Ludwig K R. Squid 1.02: A User's Manual. Berkeley Geochronology Centre, Spec Publ 2, 2001. 19

28 Ludwig K R. User's Manual for Isoplot/Ex rev. 2.49: A Geochronological Toolkit for Microsoft Excel. Brekeley Geochronology Center, Spec Publ, 2001. 55

29 Black L P, Jagodzinski E A. Importance of establishing sources of uncertainty for the derivation of reliable SHRIMP ages. Aust J Earth Sci, 2003, 50: 503-512

$30 \mathrm{Xu} \mathrm{P}, \mathrm{Wu} F \mathrm{Y}$, Xie L W, et al. Hf isotopic compositions of the standard zircons for U-Pb dating. Chin Sci Bull, 2004, 49: 1642-1648

31 Scherer E, Munker C, Mezger K. Calibration of the Lutetium-Hafnium Clock. Science, 2001, 293: 683-687

32 Blichert-Toft J, Albarède F. The Lu-Hf isotope geochemistry of chondrites and the evolution of the mantle-crust system. Earth Planet Sci Lett, 1997, 148: 243-258

33 Vervoort J D, Blichert-Toft J. Evolution of the depleted mantle: Hf isotope evidence from juvenile rocks through time. Geochim Cosmochim Acta, 1999, 63: 533-556

34 Sun S S, McDonough W F. Chemical and isotopic sysematics of oceanic basalt: implications for mantle composition and processes. In: Saunders A D, Norry M J, eds. Magmatism in the Ocean Basins. London: The Geological Society Publishing House, 1989. 313-345

35 Xiao L L, Jiang Z S, Wang G D, et al. Metamorphic reaction textures and metamorphic P-T-t loops of the Precambrian Zanhuang metamorphic complex, Hebei, North China (in Chinese). Acta Petrol Sin, 2011, 27: 980-1002

36 Xiao L L, Wu C M, Zhao G C, et al. Metamorphic P-T paths of the Zanhuang amphibolites and metapelites: Constraints on the tectonic evolution of the Paleoproterozoic Trans-North China Orogen. Int J Earth Sci, 2011, 100: 717-739

37 Trap P, Faure M, Lin W, et al. The Zanhuang Massif, the second and eastern suture zone of the Paleoproterozoic Trans-North China Orogen. Precambrian Res, 2009, 172: 80-98

38 Yang C H, Du L L, Ren L D, et al. Petrogenesis and geodynamic setting of Jiandeng potassic granite at the end of the Neoarchean in
Zanhuang Complex, North China Craton (in Chinese). Earth Sci Front, 2011, 18: 62-78

39 Yang C H, Du L L, Ren L D, et al. The age and petrogenesis of the Xuting granite in the Zanhuang Complex, Hebei Province: Constraints on the structural evolution of the Trans-North China Orogen, North China Craton (in Chinese). Acta Petrol Sin, 2011, 27: 1003-1016

40 Wood D A. The application of a Th-Hf-Ta diagram to problems of tectonomagmatic classification and to establishing the nature of crustal contamination of basaltic lavas of the British Tertiary Volcanic Province. Earth Planet Sci Lett, 1980, 50: 11-30

41 Du L L, Yang C H, Wang W, et al. The re-examination of the age and stratigraphic subdivision of the Hutuo Group in the Wutai Mountains area, North China Craton: Evidences from geology and zircon U-Pb geochronology (in Chinese). Acta Petrol Sin, 2011, 27: 1037-1055

42 Liu C H, Zhao G C, Sun M, et al. U-Pb and Hf isotopic study of detrital zircons from the Hutuo group in the Trans-North China Orogen and tectonic implications. Gondwana Res, 2011, 20: 106-121

43 Du L L, Yang C H, Guo J H, et al. The age of the base of the Paleoproterozoic Hutuo Group in Wutai Mountains area, North China Craton: SHRIMP zircon U-Pb dating of basaltic andesite. Chin Sci Bull, 2010, 55: 1782-1789

44 Yu J H, Wang D Z, Wang C Y, et al. Ages of the Lüliang Group in the Lüliang Mountains, Shanxi: Evidence from single-grain zircon U$\mathrm{Pb}$ ages (in Chinese). Geol Rev, 1997, 43: 403-408

45 Liu S W, Zhang J, Li Q G, et al. Geochemistry and U-Pb zircon ages of metamorphic volcanic rocks of the Paleoproterozoic Lüliang Complex and constraints on the evolution of the Trans-North China Orogen, North China Craton. Precambrian Res, 2011, doi: 10.1016/j. precamres.2011.07.006

46 Geng Y S, Wan Y S, Shen Q H, et al. Chronological framework of the early precambrian important events in the Lüliang area, Shanxi Province (in Chinese). Acta Geol Sin, 2000, 74: 216-223

47 Liu C H, Zhao G C, Sun M, et al. U-Pb geochronology and Hf isotope geochemistry of detrital zircons from the Zhongtiao Complex: Constraints on the tectonic evolution of the Trans-North China Orogen. Precambrian Res, 2011, doi: 10.1016/j.precamres.2011.08.007

48 Li Q G, Liu S W, Wang Z Q, et al. LA-ICP-MS U-Pb geochronology of the detrital zircons from the Jiangxian Group in the Zhongtiao Mountain and its tectonic sigificance (in Chinese). Acta Petrol Sin, 2008, 24: 1359-1368

49 Li Q, Chen X, Liu S W, et al. Evaluating the provenance of Metasedimentary rocks of the Jiangxian Group from the Zhongtiao Mountain using whole-rock geochemistry and detrital zircon Hf isotope. Acta Geol Sin, 2009, 83: 550-561

50 Sun D Z, Li H M, Lin Y X, et al. Precambrian geochronology, chronotectonic framework and model of chronocrustal structure of the Zhongtiao Mountains (in Chinese). Acta Geol Sin, 1991, 3: 216-231

51 Zhao F Q. Geochronologic and Geochemical Constraints on The Paleoproterozoic Crustal Evolution of Zhongtiao Mountains from Shanxi Province (in Chinese). Beijing: China University of Geosciences (Beijing), 2006. 161

52 Diwu C, Sun Y, Yuan H L, et al. U-Pb ages and Hf isotopes for detrital zircons from quartzite in the Paleoproterozoic Songshan Group on the southwestern margin of the North China Craton. Chin Sci Bull, 2008, 53: 2828-2839

53 Wan Y S, Liu D Y, Wang S Y, et al. Early precambrian crustal evolution in the Dengfeng area, Henan Province (eastern China): Constraints from geochemistry and SHRIMP U-Pb zircon dating (in Chinese). Acta Geol Sin, 2009, 83: 982-999

54 Liu C, Zhao G C, Sun M, et al. Detrital zircon U-Pb dating, Hf isotopes and whole-rock geochemistry from the Songshan Group in the Dengfeng Complex: Constraints on the tectonic evolution of the Trans-North China Orogen. Precambrian Res, 2012, 192-195: 1-15

55 Du L L, Yang C H, Ren L D, et al. Petrology, geochemistry and petrogenesis of the metabasalts of the Hutuo Group, Wutai Mountains, Shanxi, China (in Chinese). Geol Bull Chin, 2009, 28: 867-876

56 Yan Y Y, Wang R Z. The petro-geochemistry and tectonic setting of metabasalts in the early Proterozoic Hutuo Group (in Chinese). Contrib Geol Miner Resour Res, 1996, 11: 18-26 
57 Guo J J, Ren L D, Bai J. Analysis of the sedimentary setting of the Paleoproterozoic Hutuo Group in the Wutaishan area: Foreland basin or intracontinental rift basin? (in Chinese). Earth Sci Front, 2011, 18: 211-220

58 Yu J H, Wang D Z, Wang C Y. Geochemical characteristics and petrogenesis of the early Proterozoic bimodal volcanic rocks from Lüliang Group, Shanxi Province (in Chinese). Acta Petrol Sin, 1997, 13: 59-70

59 Geng Y S, Wan Y S, Yang C H. The Palaeoproterozoic rift-type volcanism in Lüliangshan area, Shanxi Province, and its geological significance (in Chinese). Acta Geosci Sin, 2003, 24: 97-104

60 Geng Y S, Wan Y S, Yang C H. Integrated research report on the establishment of Paleoproterozoic system of China: Determination of major Paleoproterozoic geological events and prelimary subdivision of Paleoproterozoic strata in the Lüliang area (in Chinese). Research Report on the Establishment of Major Stratigraphical Stages in China (2001-2005). Beijing: Geological Publishing House, 2008. 515-533

61 Liu S W, Li Q G, Zhang L F. Geology, geochemistry of metamorphic volcanic rock suite in Precambrian Yejishan Group, Lüliang mountains and its tectonic implications (in Chinese). Acta Petrol Sin, 2009, 25: 547-560

62 Li S, Zhao G C, Sun M, et al. Are the South and North Liaohe Groups of North China Craton different exotic terranes? Nd isotope constraints. Gondwana Res, 2006, 9: 198-208

63 Li S, Zhao G C. SHRIMP U-Pb zircon geochronology of the Liaoji granitoids: Constraints on the evolution of the Paleoproterozoic Jiao-Liao-Ji belt in the Eastern Block of the North China Craton. Precambrian Res, 2007, 158: 1-16

Open Access This article is distributed under the terms of the Creative Commons Attribution License which permits any use, distribution, and reproduction in any medium, provided the original author(s) and source are credited. 